\title{
Mineral Composition of Wild and Cultivated Blueberries
}

\author{
Paulina Dróżdż $\dot{1}^{1}$ Vaida Šéžiené $\dot{2}^{2}$ Krystyna Pyrzynska ${ }^{3}$
}

Received: 13 March 2017 / Accepted: 20 April 2017 / Published online: 9 May 2017

(C) The Author(s) 2017. This article is an open access publication

\begin{abstract}
The concentrations of 13 elements (Al, Ca, Cd, Cr, $\mathrm{Cu}, \mathrm{Fe}, \mathrm{K}, \mathrm{Mg}, \mathrm{Mn}, \mathrm{Na}, \mathrm{Ni}, \mathrm{Pb}$, and $\mathrm{Zn}$ ) were determined in several samples of native (wild) naturally growing and cultivated blueberry fruits. The total metal contents after mineralization were analyzed by inductively coupled plasma optical emission spectrometry. Reliability of the procedure was checked by the analysis of the certified reference materials Mixed Polish Herbs (INGT-MPH-2) and Leaves of Poplar (NCS DC 73350). In the fruits collected in the forest (wild blueberries), higher contents of $\mathrm{Ca}, \mathrm{Na}$, and $\mathrm{Mg}$ as well as $\mathrm{Mn}$ and $\mathrm{Zn}$ were observed. Similar levels of $\mathrm{Cu}, \mathrm{Cr}, \mathrm{Fe}$, and $\mathrm{Ni}$ were detected in both wild-growing and cultivated plants. The significantly higher content of $\mathrm{Fe}$ and $\mathrm{Cd}$ in cultivated blueberries was connected with the content of these metals in soil samples collected from the same places. The metal extraction efficiency by hot water varied widely for the different blueberries (wild or cultivated) as well as their form (fresh or dried).
\end{abstract}

Keywords Blueberry $\cdot$ Wild growing $\cdot$ Cultivated $\cdot$ Element analysis $\cdot$ Water extraction

Krystyna Pyrzynska

kryspyrz@chem.uw.edu.pl

1 Laboratory of Natural Environment Chemistry, Forest Research Institute, Sękocin Stary, Poland

2 Ecology Department, Lithuanian Research Centre for Agriculture and Forestry, Kaunas distr., Lithuania

3 Department of Chemistry, University of Warsaw, Pasteura 1, 02-093 Warsaw, Poland

\section{Introduction}

Among the colorful berries, Vaccinium corymbosum, also called American the blueberry, and the wild-growing blueberry Vaccinium myrtillus L. (called bilberry) are popularly used in the human diet either fresh or in processed forms. Additionally, there has been a growing trend in the use of blueberry extracts as ingredients in functional foods and dietary supplements. They are a rich source of flavonoids, phenolic acids, anthocyanins, stilbenes, and tannins, as well as nutritive compounds such as sugars, essential oils, carotenoids, vitamins, and minerals [1]. Bioactive compounds from blueberries have potent antioxidant, anticancer, antimicrobial, and anti-inflammatory properties, both in vitro and in vivo [1-3]. Blueberry fruits have been used in the traditional medicine internally (directly or as tea or liqueur) for treatment of disorders of the gastrointestinal tract and diabetes. Herbal supplements of V. myrtillus on the market are used for circulatory problems, as vision aids, and to treat diarrhea [4]. It was found that the consumption of wild blueberry drink for 6 weeks significantly reduced the levels of oxidized DNA bases and increased the resistance to oxidatively induced DNA damage [5].

Bilberries and American blueberries are nearly identical and used for the same purposes. Wild blueberry is found natively in Europe, northern Asia, western USA, and Canada. Unlike cultivated (highbush) blueberries, wild (lowbush) blueberries are not planted but spread primarily by rhizomes or underground runners, which give rise to new shoots and stems. Fruits are mostly collected from wild plants growing on publicly accessible lands, and you can buy them at the local markets. American blueberries, usually cultivated, grow on large bushes with the fruit in bunches and are widely available commercially.

The content of anthocyanins and other phenolic compounds in different species of blueberry (wild and cultivated) 
are quite often determined and compared [6-10]. Concentration of essential elements, which are also the important components of blueberry fruits, was rarely reported [11, 12]. Trace elements play an important role in the functioning of the human body. They mainly act as cofactors for various enzymatic systems (generally redox-active metals) or possess regulatory activity [13]. On the other hand, the toxic trace elements impair physiological function via the induction of universal pathogenetic pathways such as oxidative stress, inflammation, and endoplasmic reticulum stress [14].

Blueberries retain their maximum amount of nutrients and taste when they are enjoyed fresh. During the winter when fresh fruits are not available, dried blueberries can be used in the form of tea. In folk medicine, the extract from dried blueberries have been used to treat diarrhea and inflammation of the mouth or throat [4]. The study conducted by Miyake al. [15] indicated that such extract had a protective effect on visual function during retinal inflammation. The soup prepared from blueberries is also often served warm in winter or cold in summer.

The objective of this study was to investigate the level of several elements ( $\mathrm{Al}, \mathrm{Ca}, \mathrm{Cd}, \mathrm{Cr}, \mathrm{Cu}, \mathrm{Fe}, \mathrm{K}, \mathrm{Mg}, \mathrm{Mn}, \mathrm{Na}, \mathrm{Ni}$, $\mathrm{Pb}$, and $\mathrm{Zn}$ ) in native (wild) naturally growing and cultivated blueberry fruit samples. Additionally, the efficiency of extraction of these metal ions by hot water from fresh as well as dried blueberries were compared.

\section{Materials and Methods}

\section{Sample Description}

The fruits of wild-growing blueberries were collected during September of 2016, in three different locations in central Poland (the Mazovia region). Sample W1 was from a 12year-old pine forest (N $52^{\circ} 41^{\prime}$, E $\left.21^{\circ} 29^{\prime}\right)$, sample W2 from a 25-year old pine forest (N $52^{\circ} 49^{\prime}$, E $\left.21^{\circ} 45^{\prime}\right)$, and sample $\mathrm{W} 3$ from a 77 -year-old pine wood (N $\left.52^{\circ} 01^{\prime}, \mathrm{E} 21^{\circ} 06^{\prime}\right)$. The berries were harvested optimally ripe based on color, flavor, and structure.

Additionally, one sample (W4) was obtained from the local marketplace. One sample of cultivated American blueberries was purchased from a local market (sample C1), and the second one (sample $\mathrm{C} 2$ ) was collected from the garden plot outside Warsaw city (Poland).

Once the samples were collected, they were frozen and stored in a freezer at $-20{ }^{\circ} \mathrm{C}$. For analysis, the samples were thawed at refrigerator temperature $\left(\sim 4{ }^{\circ} \mathrm{C}\right)$ and homogenized by blender.

\section{Preparation of Samples}

For determination of metal contents, the samples were digested using the mixture of concentrated acids $\mathrm{HNO}_{3}$ and
$\mathrm{HClO}_{4}(4: 1 v / v) .0 .5 \mathrm{~g}$ of fruit sample was placed into a $100-\mathrm{mL}$ flask, and $10 \mathrm{~mL}$ of acid mixture was added to it. This mixture was heated for $30 \mathrm{~min}$ at $50^{\circ} \mathrm{C}$ on the hot plate. Then, the temperature was slowly raised to $160-170{ }^{\circ} \mathrm{C}$, and digestion was performed at the beginning for $120 \mathrm{~min}$ and finally at $200{ }^{\circ} \mathrm{C}$ for $60 \mathrm{~min}$. The digested sample solution was allowed to cool down and transferred into a $50-\mathrm{mL}$ volumetric flask diluted by adding distilled water. As the level of $\mathrm{Cd}$ and $\mathrm{Cr}$ in the analyzed samples was very low, additional digestion procedure was performed using higher amount of analyzed fruits $(5 \mathrm{~g})$.

Digestion of a reagent blank was performed in parallel.

Drying of fruits was performed in a laboratory dryer at $60{ }^{\circ} \mathrm{C}$ for $24 \mathrm{~h}$.

For extraction of metals from fresh or dried blueberries, $20 \mathrm{~mL}$ of freshly boiled $\left(\sim 95^{\circ} \mathrm{C}\right)$ distilled water was added to $0.7 \mathrm{~g}$ of appropriate fruits. After $20 \mathrm{~min}$ of brewing and subsequent cooling, the samples were centrifuged and transferred to volumetric flasks and diluted to a final volume of $25.0 \mathrm{~mL}$. The extracts were prepared directly before analysis, and all determinations were carried out in triplicate.

\section{Element Analysis}

The concentration of elements ( $\mathrm{Al}, \mathrm{Ca}, \mathrm{Cd}, \mathrm{Cr}, \mathrm{Cu}, \mathrm{Fe}, \mathrm{K}, \mathrm{Mg}$, $\mathrm{Mn}, \mathrm{Na}, \mathrm{Ni}, \mathrm{Pb}$, and $\mathrm{Zn}$ ) were determined by inductively coupled plasma (ICP OES) using a Thermo Scientific spectrometer, model iCAP 6000 . The operating parameters set to the spectrometer were those recommended by its manufacturer, i.e., the forward power of $1.15 \mathrm{~kW}$, the Ar auxiliary gas flow rate of $0.2 \mathrm{~L} / \mathrm{min}$, the Ar nebulizing gas flow rate of $0.42 \mathrm{~L} / \mathrm{min}$, and coolant gas flow rate of $12 \mathrm{~L} / \mathrm{min}$. The intensity readings were repeated three times using the integration time of $1 \mathrm{~s}$. The most prominent lines of the studied metals were selected, i.e., Al $396.1 \mathrm{~nm}, \mathrm{Ca} 317.9 \mathrm{~nm}, \mathrm{Cd} 214.4 \mathrm{~nm}$, Cr 267.7 nm, Cu 224.7 nm, Fe 259.9 nm, K 766.4 nm, Mg $285.2 \mathrm{~nm}$, Mn $260.5 \mathrm{~nm}$, Na $589.5 \mathrm{~nm}$, Ni $231.6 \mathrm{~nm}, \mathrm{~Pb}$ $220.3 \mathrm{~nm}$, and Zn $206.2 \mathrm{~nm}$.

\section{Results and Discussion}

The total metal concentration in the digested samples of berries was determined by ICP OES method. In order to validate the analytical protocol, linearity of the calibration curve range for each element generated by injection of standard solutions as well as limit of quantification (LOQ) were evaluated. The validation data of the analytical methodology are summarized in Table 1.

Recovery experiments were performed for all the elements at their concentration ranges similarly found in berry fruits. The observed recoveries (data not shown) ranged between 87 and $109 \%$, with the relative standard deviations lower than 
Table 1 Validation parameters obtained for analyzed elements using ICP OES

\begin{tabular}{lllll}
\hline Element & Concentration range $(\mathrm{mg} / \mathrm{L})$ & $R^{2}$ & $\begin{array}{l}\mathrm{LOQ} \\
(\mathrm{mg} / \mathrm{kg})\end{array}$ & $\begin{array}{l}\mathrm{CV} \\
(\%)\end{array}$ \\
\hline $\mathrm{Al}$ & $1-20$ & 0.9997 & 1.0 & 3.2 \\
$\mathrm{Ca}$ & $10-200$ & 0.9999 & 0.2 & 1.0 \\
$\mathrm{Cd}$ & $0.001-0.2$ & 0.9999 & 0.0003 & 2.6 \\
$\mathrm{Cr}$ & $0.05-1$ & 1.0000 & 0.03 & 2.3 \\
$\mathrm{Cu}$ & $0.25-5$ & 0.9999 & 0.5 & 1.3 \\
$\mathrm{Fe}$ & $0.5-10$ & 0.9999 & 0.5 & 1.5 \\
$\mathrm{Mg}$ & $1-30$ & 0.9999 & 2.0 & 1.6 \\
$\mathrm{Mn}$ & $2-40$ & 0.9996 & 0.05 & 0.9 \\
$\mathrm{Na}$ & 110 & 0.9999 & 5.0 & 4.0 \\
$\mathrm{Ni}$ & $0.05-1$ & 0.9999 & 0.2 & 4.0 \\
$\mathrm{~Pb}$ & $0.05-1$ & 0.9999 & 0.5 & 2.9 \\
$\mathrm{Zn}$ & $0.2-4$ & 0.9999 & 0.3 & 1.0 \\
\hline
\end{tabular}

$C V$ coefficient of variation, $L O Q$ limit of quantification, $R$ correlation coefficient

$10 \%$ in all cases. These results confirmed that no significant metal losses occurred during the digestion procedure. To verify the applicability of the proposed method, standard reference materials Mixed Polish Herbs (INGT-MPH-2) and Leaves of Poplar (NCS DC 73350) were also utilized. Digestion of these materials was performed with the same decomposition procedure used for the blueberry samples. The obtained experimental results were compared with those provided by the manufacturers and are presented in Table 2 .
The results concerning the analyzed elements in different samples of wild and cultivated blueberry samples are presented in Table 3. All the results, expressed in milligram per kilogram on wet weight basis, are characterized by mean value with the corresponding standard deviation. Generally, in fruits collected in the forest (wild blueberries), higher levels of macroelements such as $\mathrm{Ca}, \mathrm{Na}$, and $\mathrm{Mg}$ (metals of natural soil origin) were observed in comparison with cultivated highbush blueberries. These minerals are dietary requirements in human nutrition and have various physiological effects. The values for $\mathrm{Ca}$ and $\mathrm{Mg}$ are at least 10-fold lower than those of potassium. This fact is common for almost all types of plants because potassium is more mobile in the xylem and phloem (vascular tissues that perform transportation of food and water in a plant) than calcium or magnesium and this element tends to be more concentrated in various parts of the plant [16]. Among microelements, higher contents of $\mathrm{Mn}$ and $\mathrm{Zn}$ were detected in naturally growing plants. Manganese is an essential element and is bound to a number of essential enzymes, for example, the activity of superoxide dismutase is suppressed by low $\mathrm{Mn}$ status [17]. Similar levels of $\mathrm{Cu}, \mathrm{Cr}, \mathrm{Fe}$, and $\mathrm{Ni}$ were detected in both wild-growing and cultivated plants.

Significantly higher content of cadmium was detected in fruits of farm-raised in comparison to wild cultivars. It can be explained by the much higher $\mathrm{Cd}$ content in the soil sample collected from the same place $(0.398 \mathrm{mg} / \mathrm{kg})$ in comparison with $0.041-0.087 \mathrm{mg} / \mathrm{kg}$ determined in soils, where W1-W4 samples were grown. According to The Commission of the European Communities [18], the maximum allowed levels for
Table 2 Analysis of certified reference materials (in $\mathrm{mg} / \mathrm{kg}$, $n=3$ )

\begin{tabular}{llllll}
\hline Element & $\begin{array}{l}\text { Mixed Polish Herbs } \\
\text { (INGT-MPH-2) }\end{array}$ & & \multicolumn{2}{l}{$\begin{array}{l}\text { Leaves of Poplar } \\
\text { (NCS DC 73350) }\end{array}$} \\
\cline { 2 - 3 } \cline { 5 - 6 } & Certified & Determined & & Certified & Determined \\
\hline $\mathrm{Al}$ & $670 \pm 111$ & $667 \pm 10.4$ & & $1040 \pm 60$ & $1035 \pm 13$ \\
$\mathrm{Ca}$ & $10,800 \pm 700$ & $10,839 \pm 176$ & & $18,100 \pm 1300$ & $181,774 \pm 267$ \\
$\mathrm{Cd}$ & $0.199 \pm 0.015$ & $0.203 \pm 0.040$ & & $0.32 \pm 0.07$ & $0.32 \pm 0.01$ \\
$\mathrm{Cr}$ & $1.69 \pm 0.13$ & $1.67 \pm 0.03$ & & $0.55 \pm 0.07$ & $0.55 \pm 0.01$ \\
$\mathrm{Cu}$ & $7.77 \pm 0.53$ & $7.97 \pm 0.41$ & & $9.3 \pm 1.0$ & $9.23 \pm 0.23$ \\
$\mathrm{Fe}$ & $460^{\mathrm{a}}$ & $465 \pm 7.11$ & & $274 \pm 17$ & $271 \pm 6.06$ \\
$\mathrm{~K}$ & $19,100 \pm 120$ & $19,135 \pm 193$ & & $13,800 \pm 700$ & $13,726 \pm 290$ \\
$\mathrm{Mg}$ & $2920 \pm 160$ & $2913 \pm 88.3$ & & $6500 \pm 49$ & $6549 \pm 75$ \\
$\mathrm{Mn}$ & $191 \pm 12$ & $194 \pm 6.99$ & & $45 \pm 4$ & $45.0 \pm 0.97$ \\
$\mathrm{Na}$ & $350^{\mathrm{a}}$ & $357 \pm 7.09$ & & $200 \pm 13$ & $198 \pm 7.11$ \\
$\mathrm{Ni}$ & $1.57 \pm 0.16$ & $1.55 \pm 0.04$ & & $1.9 \pm 0.3$ & $1.91 \pm 0.05$ \\
$\mathrm{~Pb}$ & $2.16 \pm 0.23$ & $2.16 \pm 0.05$ & & $1.5 \pm 0.3$ & $1.49 \pm 0.08$ \\
$\mathrm{Zn}$ & $33.5 \pm 2.1$ & $33.1 \pm 0.08$ & $37 \pm 3$ & $37.3 \pm 0.56$ \\
\hline
\end{tabular}

${ }^{\mathrm{a}}$ Information value 
Table 3 Content of elements in different blueberry samples in $\mathrm{mg} / \mathrm{kg}($ mean $\pm \mathrm{SD}, n=3)$

\begin{tabular}{lccccccc}
\hline Sample & $\mathrm{Al}$ & $\mathrm{Ca}$ & $\mathrm{Cd}$ & $\mathrm{Cr}$ & $\mathrm{Cu}$ & $\mathrm{Fe}$ \\
W1 & $14.8 \pm 0.55 \mathrm{a}$ & $185 \pm 9.7 \mathrm{a}$ & $0.004 \pm 0.0003 \mathrm{a}$ & $0.039 \pm 0.002 \mathrm{a}$ & $0.31 \pm 0.017 \mathrm{a}$ & $8.38 \pm 0.33 \mathrm{a}$ & $880 \pm 27 \mathrm{a}$ \\
W2 & $12.4 \pm 0.60 \mathrm{~b}$ & $164 \pm 7.9 \mathrm{~b}$ & $0.002 \pm 0.0001 \mathrm{~b}$ & $0.174 \pm 0.008 \mathrm{~b}$ & $0.26 \pm 0.012 \mathrm{~b}$ & $7.82 \pm 0.39 \mathrm{a}$ & $1036 \pm 51 \mathrm{~b}$ \\
W3 & $15.1 \pm 0.67 \mathrm{a}$ & $203 \pm 8.9 \mathrm{ac}$ & $0.001 \pm 0.0005 \mathrm{c}$ & $0.023 \pm 0.001 \mathrm{c}$ & $0.24 \pm 0.013 \mathrm{c}$ & $5.31 \pm 0.25 \mathrm{~b}$ & $1090 \pm 52 \mathrm{~b}$ \\
W4 & $16.3 \pm 0.73 \mathrm{a}$ & $192 \pm 8.7 \mathrm{ac}$ & $0.003 \pm 0.0001 \mathrm{~d}$ & $0.084 \pm 0.004 \mathrm{~d}$ & $0.41 \pm 0.016 \mathrm{~d}$ & $12.7 \pm 0.64 \mathrm{c}$ & $1105 \pm 53 \mathrm{~b}$ \\
$\mathrm{C} 1$ & $13.3 \pm 0.91$ & $112 \pm 5.1 \mathrm{~d}$ & $0.013 \pm 0.0006 \mathrm{e}$ & $0.033 \pm 0.006 \mathrm{e}$ & $0.28 \pm 0.011 \mathrm{abce}$ & $5.44 \pm 0.27 \mathrm{~d}$ & $825 \pm 15 \mathrm{a}$ \\
$\mathrm{C} 2$ & $17.9 \pm 0.80$ & $162 \pm 6.1 \mathrm{~b}$ & $0.040 \pm 0.0015 \mathrm{f}$ & $0.014 \pm 0.001 \mathrm{e}$ & $0.32 \pm 0.014 \mathrm{ae}$ & $10.7 \pm 0.52 \mathrm{~d}$ & $1031 \pm 28 \mathrm{~b}$ \\
& $\mathrm{Mg}$ & $\mathrm{Mn}$ & $\mathrm{Na}$ & $\mathrm{Ni}$ & $\mathrm{Pb}$ & $2 \mathrm{n}$ \\
W1 & $84.2 \pm 6.92 \mathrm{a}$ & $17.1 \pm 1.03 \mathrm{a}$ & $52.7 \pm 1.93 \mathrm{a}$ & $0.263 \pm 0.019 \mathrm{a}$ & $0.556 \pm 0.063 \mathrm{a}$ & $6.07 \pm 0.75 \mathrm{a}$ \\
W2 & $75.1 \pm 3.09 \mathrm{a}$ & $5.82 \pm 0.16 \mathrm{~b}$ & $54.0 \pm 1.78 \mathrm{a}$ & $0.254 \pm 0.012 \mathrm{a}$ & $0.373 \pm 0.018 \mathrm{~b}$ & $5.26 \pm 0.26 \mathrm{ab}$ \\
W3 & $96.9 \pm 2.11 \mathrm{~b}$ & $29.0 \pm 1.35 \mathrm{c}$ & $54.9 \pm 2.03 \mathrm{a}$ & $0.252 \pm 0.011 \mathrm{a}$ & $0.266 \pm 0.013 \mathrm{~b}$ & $4.22 \pm 0.17 \mathrm{bcd}$ \\
W4 & $90.1 \pm 3.42 \mathrm{~b}$ & $18.5 \pm 0.88 \mathrm{a}$ & $61.6 \pm 2.97 \mathrm{~b}$ & $0.312 \pm 0.015 \mathrm{~b}$ & $0.396 \pm 0.018 \mathrm{ab}$ & $3.83 \pm 0.15 \mathrm{c}$ \\
C1 & $51.4 \pm 2.60 \mathrm{c}$ & $4.47 \pm 0.13 \mathrm{~d}$ & $48.1 \pm 2.12 \mathrm{c}$ & $0.170 \pm 0.008 \mathrm{a}$ & $0.276 \pm 0.014 \mathrm{~b}$ & $2.95 \pm 0.15 \mathrm{ce}$ \\
C2 & $48.1 \pm 2.07 \mathrm{c}$ & $2.94 \pm 0.015 \mathrm{e}$ & $49.2 \pm 2.63 \mathrm{c}$ & $0.299 \pm 0.015 \mathrm{a}$ & $0.315 \pm 0.015 \mathrm{~b}$ & $3.79 \pm 0.19 \mathrm{~cd}$ \\
\hline
\end{tabular}

Values followed by the same letters in each column ( $\mathrm{a}, \mathrm{b}, \mathrm{c}, \mathrm{d}$ ) have no significant difference (Tukey's test, $p>0.05$ ).

$W$ stands for wild blueberry and $C$ stands for cultivated American blueberry (see experimental).

$\mathrm{Cd}$ and $\mathrm{Pb}$ are 0.05 and $0.2 \mathrm{mg} / \mathrm{kg}$, respectively, which are higher than the values detected in this study. Hence, none of these berries would represent a risk to human health from this point of view. Vollmannova et al. [11] found higher $\mathrm{Cu}, \mathrm{Zn}$, and $\mathrm{Pb}$ and similar $\mathrm{Cd}$ contents in wild blueberries collected in Slovakia in comparison with highbush blueberry cultivar; however, the soil content where the fruits were grown was not examined.

In the present study, the Fe concentration in cultivated blueberries is higher than that in other reports $[12,16]$, probably due to soil conditions. The sample was collected from the garden plot where acidic soil with high content of Fe $(4260 \mathrm{mg} / \mathrm{kg})$ as well as $\mathrm{Al}(3000 \mathrm{mg} / \mathrm{kg})$ dominates. A similar behavior for iron in different berry fruits cultivated in Brazil has been reported [19]. That fact can justify our results.

Considering the content of individual elements, statistically significant differences were observed among the wildgrowing blueberries collected in different locations (samples W1-W4). These variations were probably due to different growing conditions, soil load, and soil properties as well as periodic changes in pollution of soil, water, and air [20]. Although, we selected a limited area for sample collection in order to have uniform climatic conditions. The results of oneway ANOVA followed by Tukey's test indicated that the contents of $\mathrm{Cd}, \mathrm{Cr}, \mathrm{Cu}$, and $\mathrm{Mn}$ vary significantly $(p<0.05)$ among all four studied samples.

Blueberries, in fresh or dry form, can be also used for preparation of hot or cold beverages such as tea, juice, or syrup. Thus, it was interesting to check the efficiency of extraction of metal ions by hot water from the fresh as well as from the dried blueberry fruits under study. Samples W1 and $\mathrm{C} 2$ (wild and cultivated berries) were chosen for these
A)

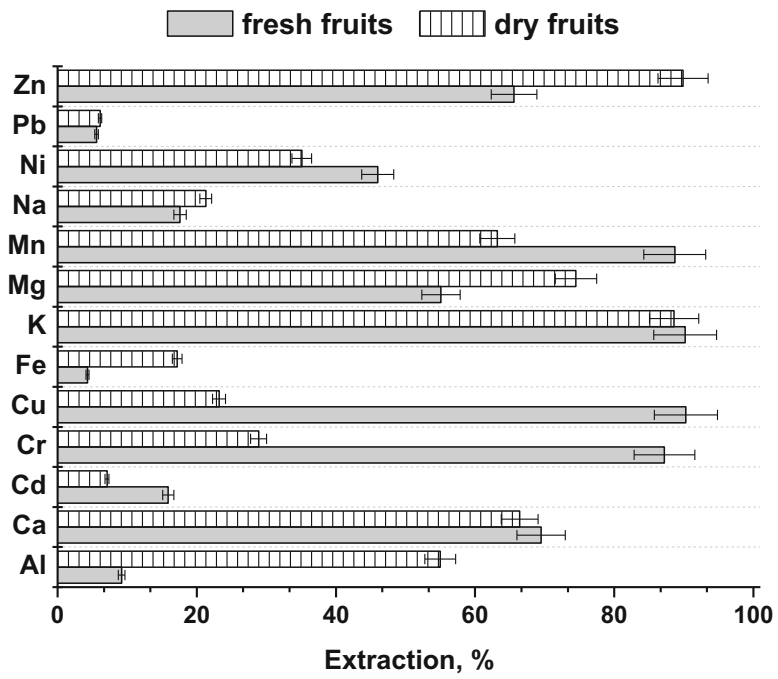

B)

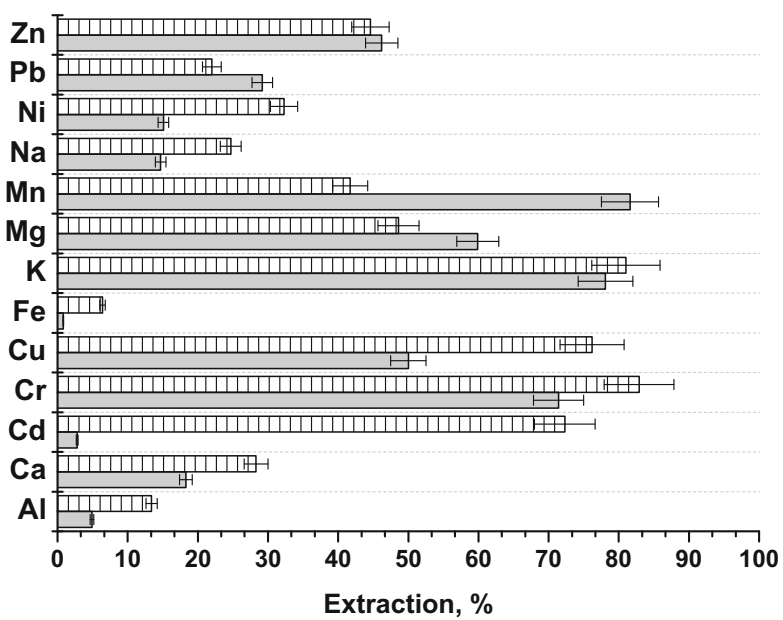

Fig. 1 Efficiency of extraction of metal ions from a wild blueberries (sample W1) and b cultivated blueberries (sample C2). Fresh fruits, dry fruits 
experiments. Drying of these fruits was performed at $60^{\circ} \mathrm{C}$ for $24 \mathrm{~h}$, and acidic digestion was then performed with the same procedure as for fresh fruits. Extraction of metals was performed using $20 \mathrm{~mL}$ of freshly boiled distilled water for $20 \mathrm{~min}$. Concentration of metals in the obtained infusions was determined by ICP OES method. The obtained results are presented in Fig. 1. The metal extraction efficiency varied widely for the different blueberries (wild or cultivated) as well as their form (fresh or dried). Generally, the percent of extraction exceeded $80 \%$ for $\mathrm{K}, \mathrm{Cr}$, and $\mathrm{Cu}$ (only for fresh fruits) from all types of fruits. Also the efficiency of extraction for $\mathrm{Mn}$ from both wild blueberries and $\mathrm{Zn}$ from fresh fruits are very high. The low extractability of $\mathrm{Fe}$ was also reported from different kinds of tea [21]. However, the bioaccessibility of this element is greater than that in the other berry fruits [16]. Interesting, the leaching of toxic elements such as $\mathrm{Pb}$ and $\mathrm{Cd}$ from fresh and dried wild blueberries was very little.

\section{Conclusion}

The mineral composition of wild and cultivated blueberries has been determined by ICP OES after mineralization. Forest (wild blueberries) proved to be good sources of $\mathrm{Ca}$, $\mathrm{Na}$, and $\mathrm{Mg}$ as well as $\mathrm{Mn}$ and $\mathrm{Zn}$. Mn is also extracted with hot water either from fresh or dried wild blueberries to a great extent. Moreover, only low contents of toxic elements such as $\mathrm{Pb}$ and $\mathrm{Cd}$ were detected, ensuring the absence of risk for human health.

Open Access This article is distributed under the terms of the Creative Commons Attribution 4.0 International License (http:// creativecommons.org/licenses/by/4.0/), which permits unrestricted use, distribution, and reproduction in any medium, provided you give appropriate credit to the original author(s) and the source, provide a link to the Creative Commons license, and indicate if changes were made.

\section{References}

1. Nile SH, Park SW (2014) Edible berries: bioactive components and their effect on human health. Nutrition 30:134-144

2. Samad NB, Debnath T, Ye M, Hasnat MA, Lim BQ (2014) In vitro antioxidant and anti-inflammatory activities of Korean blueberry (Vaccinium corymbosum L.) extracts. Asian Pac J Trop Biomed 4: 807-815

3. Hwang SJ, Yoon WB, Lee OH, Cha SJ, Kim JD 92014) Radicalscavenging-kinked antioxidant activities of extracts from black chokeberry and blueberry cultivated in Korea. Food Chem 146: 71-77

4. Vogl S, Picker P, Mihaly-Bison J, Fakhrudin N, Atanasov AG, Heiss EH, Wawrosch C, Reznicek G, Dirsch VM, Saukel J, Kopp B (2013) Ethnopharmacological in vitro studies on Austria's folk medicine - an unexplored lore in vitro anti-inflammatory activities of 71 Austrian traditional herbal drugs. J Ethnopharmacol 149:750 771

5. Riso P, Zacas DK, Del Bo C, Martini D, Campolo J, Vendrame S, Möller P, Loft S, De Maria R, Porrini M (2013) Effect of a wild blueberry (Vaccinium angustifolium) drink intervention on markers of oxidative stress, inflammation and endothelia function in humans with cardiovascalar risk factors. Eur J Nutr 52:949-961

6. Latti AK, Riihinen KR, Kainulainen PS (2008) Analysis of anthocyanin variation in wild populations of bilberry (Vaccinium myrtillus L.) in Finland. J Agric Food Chem 56:190-196

7. Barnes JS, Nguyen HP, Shen S, Schug KA (2009) General method for extraction of blueberry anthocyanins and identification using high performance liquid chromatography-electrospray ionizationion trap-time of flight-mass spectrometry. J Chromatogr A 1216: $4728-4735$

8. Garzón GA, Narváez CE, Riedl KM, Schwartz SJ (2010) Chemical composition, anthocyanins, non-anthocyanin phenolics and antioxidant activity of wild bilberry (Vaccinium meridionale Swartz) from Colombia. Food Chem 122:980-986

9. Wang SY, Chen H, Camp MJ, Ehlrenfeldt MK (2012) Flavonoid constituents and their contribution to antioxidant activity in cultivars and hybrids of rabbiteye blueberry (Vaccinium ashei Reade). Food Chem 132:855-864

10. Primetta AK, Jaakola L, Ayaz FA, Inceer H, Riihinen KR (2013) Anthocyanin fingerprinting authenticity studies of bilberry (Vaccinium myrtillus L.) Food Cntrol 30:662-667

11. Vollmannova A, Musilova J, Toth T, Arvay J, Bystricka J, Medvecky M, Daniel J (2014) Phenolic compounds, antioxidant activity and $\mathrm{Cu}, \mathrm{Zn}, \mathrm{Cd}$ and $\mathrm{Pb}$ content in wild and cultivated cranberries and blueberries. Intern J Environ Anal Chem 94:1445-1451

12. Zhang H, Wang ZY, Yang X, Zhao HT, Zhang YC, Dong AJ, Jing WJ (2014) Determination of free amino acid and 18 elements in freeze-dried strawberry and blueberry fruit using an Amino Acid Analyzer and ICP-MS with micro-wave digestion. Food Chem 147: 189-194

13. Fraga CG (2005) Relevance, essentiality and toxicity of trace elements in human health. Mol Asp Med 26:235-244

14. Jomova K, Valko M (2011) Advances in metal-induced oxidative stress and human disease. Toxicology 283:65-87

15. Miyake S, Takahashi N, Sasaki M, Kobayashi S, Tsubota K, Ozawa Y (2012) Vision preservation during retinal inflammation by anthocyanin-rich bilberry extract: cellular and molecular mechanism. Lab Investig 92:102-109

16. Pereira CC, da Silva EN, de Souza AO, Vieira MA, Ribeiro AS, Cadore S (2016) Evaluation of the bioaccessibility of minerals from blackberries, raspberries, blueberries and strawberries. J Food Comp Anal http://dx.doi.org/10.1016/j.fca.2016.12.001

17. Li C, Zhou HM (2011) The role of manganese superoxide dismutase in inflammation defence. Enzyme Res Article ID 387176

18. Commission of the European Communities (2006) Commission Regulation (EC) No 1881/2006 Setting maximum levels for certain contaminants in foodstuffs. Off J Eur Union L364:5-24

19. de Souza VR, Pereira PA, da Silva TL, de Oliveira Lima LC, Pio R, Queiroz F (2014) Determination of the bioactive compounds, antioxidant activity and chemical composition of Brazilian blackberry, red raspberry, strawberry, blueberry and sweet cherry fruits. Food Chem 156:362-368

20. Nordløkken M, Berg T, Flaten TP, Steinnes E (2015) Essential and non-essential elements in natural vegetation in southern Norway: contribution from different sources. Sci Total Environ 502:391-399

21. Pękal A, Biesaga M, Pyrzynska K (2013) Trace metals and flavonoids in different types of tea. Food Sci Biotechnol 22:925-930 